\title{
Screening of Ipomoea tuba Leaf Extract for Identification of Bioactive Compounds and Evaluation of Its in vitro Antiproliferative Activity Against MCF-7 and HeLa Cells
}

\section{Thirupati Chinna \\ Venkateswarulu'•, Gaddam \\ Eswaraiah $\oplus$, Srirama \\ Krupanidhi'®, Karlapudi \\ Abraham Peele $\oplus^{\top}$, Indira \\ Mikkili ${ }^{\top}$, Alugunulla \\ Venkata Narayana'๑, \\ Bharath Kumar Ravuru²®, \\ John Babu Dulla'๑ and \\ Ranga Rao Ambati** ${ }^{*}$ \\ 'Department of Bio-Technology, Vignan's Foundation for Science, Technology \& Research (Deemed to be University), Vadlamudi-522213, Guntur, Andhra Pradesh, India ${ }^{2} S$ chool of Life Sciences, Rayalaseema University, Kurnool-518002, Andhra Pradesh, India}

Received: 2 May 2019 Accepted: 17 March 2020

\section{SUMMARY}

Mangroves contain a wide range of bioactive compounds with pharmacological activities. In the present study, we analysed the separation and detection of phytoconstituents with the methanol extract of Ipomoea tuba leaf using gas chromatography-mass spectrometry (GC-MS) and tested its in vitro cytotoxicity effect against MCF-7 and HeLa cells. Phytochemical compounds such as docosanoic, octadecatrienoic and cis-9-octadecanoic acids, triterpenoid $\gamma$-sitosterol, and terpene alcohol in methanol extract of $I$. tuba leaf were identified. Furthermore, in vitro antiproliferative activity of the extract of $I$. tuba leaf was evaluated using MCF-7 and HeLa cells. The results indicated a reduction of cell viability of 37.43 and $41.89 \%$ of MCF-7 and HeLa cells respectively. The methanol extract of I. tuba leaf proved to be effective in protecting the cells against oxidative stress. This is the first report on the in vitro cytotoxicity effect of I. tuba leaf extract on MCF-7 and HeLa cells.

Key words: mangrove species, Ipomoea tuba, bioactive compounds, antiproliferative activity

\section{INTRODUCTION}

Mangrove ecosystem plays a major role in the human life to protect us from natural disasters like tsunami, floods, high tides and soil erosion. Mangrove plants grow in water logging region and offer a shelter for wide ranges of endemic fauna and flora $(1,2)$. They absorb and remove five times more carbon dioxide than normal terrestrial plants (3). The mangrove species, namely Suaeda maritima, commonly known as seablite is used in homemade foods such as salad, curry, soy sauce, and spicy soup in Thailand (4). In recent years, bioactive compounds produced from the plants have attracted the interest of pharmaceutical industries for formulation of drugs because the effectiveness of synthetic antibiotics against several pathogenic strains is slowly decreasing (5). The natural compounds and related drugs are used to treat different human diseases (6). The crude methanol extract of different medicinal plants contains many bioactive compounds having anticancer activity against several cancers like gastric, coIon and breast cancer cell lines (7). Phytoconstituents and cytotoxicity of $I$. tuba have not been studied so far. Hence, the present study aims to evaluate the phytoconstituents of methanol extract of $I$. tuba leaf and their cytotoxicity effects on MCF-7 and HeLa cells.

\section{MATERIALS AND METHODS}

\section{Sample preparation}

Ipomoea tuba sample was collected from Nizampatnam mangroves, Guntur, Andhra Pradesh, India. The sample was prepared from leaves of $I$. tuba by soaking $50 \mathrm{~g}$ of powdered sample in $50 \mathrm{~mL}$ of absolute methanol for $72 \mathrm{~h}$. The sample was filtered through Whatman No. 42 filter paper and then methanol was evaporated from the test sample by rotary vacuum evaporator (EV11; Equitron Medica Pvt Ltd, Mumbai, India). The final crude extract was dissolved in $100 \%$ dimethyl sulfoxide (DMSO; Sigma-Aldrich Chemicals Pvt Ltd, Merck, Bangalore, India), made to final concentration of $100 \mathrm{mg} / \mathrm{mL}$ and used for antiproliferative studies. The concentration of DMSO maintained in the wells was less than $1 \%$, which is not toxic to the cell lines $(8,9)$. 


\section{Identification of compounds by GC-MS analysis}

Bioactive compounds in leaf extract of $I$. tuba were identified by GC-MS (6890 series; Agilent, Santa Clara, CA, USA). The following chromatographic conditions were maintained: initial column temperature $30^{\circ} \mathrm{C}$, heated up to $300{ }^{\circ} \mathrm{C}$ at 10 ${ }^{\circ} \mathrm{C} / 5 \mathrm{~min}$, flow rate $1.0 \mathrm{~mL} / \mathrm{min}$ and helium was used as carrier gas in split mode. The bioactive compounds were identified based on retention times and quantified by integration of peak area. Similarity of compounds was compared with known compounds using NIST-based AMDIS software (10).

\section{3-(4,5-Dimethylthiazol-2-yl)-2,5-diphenyltetrazolium bromide (MTT) assay for cell viability}

Ipomoea tuba leaf extract was screened for in vitro cytotoxicity activity on MCF-7 and HeLa cells ( $5 \cdot 10^{3}$ cell/well) using MTT (Sigma-Aldrich, Merck, St. Louis, MO, USA) assay. The sample ( $100 \mu \mathrm{L}$ diluted plant extract) was added to $100 \mu \mathrm{L}$ of Dulbecco's Modified Eagle's medium (DMEM), then the cell lines were added to the 96-well microtiter plate, and incubated for $48 \mathrm{~h}$ at $37^{\circ} \mathrm{C}$. The MTT was added and allowed to incubate for $2 \mathrm{~h}$ until the purple precipitate was formed. Then, absorbance values were measured at $520 \mathrm{~nm}$ using UV-Vis spectrophotometer (Cary 60; Agilent Technologies, Selangor Darul Ehsan, Malaysia). The dose-response curve was plotted for evaluation of $\mathrm{IC}_{50}$ values (11).

\section{Statistical analysis}

The experimental data of both cell lines were statistically analyzed using ANOVA method. The value $p<0.05$ is considered statistically significant for the analysis of the percentage of inhibition of cell viability.

\section{RESULTS AND DISCUSSION}

\section{GC-MS analysis for compound identification}

The chromatogram confirmed the presence of compounds such as fatty acids: docosanoic, octadecatrienoic and cis-9-octadecanoic acids, triterpenoid $\mathrm{\gamma}$-sitosterol, and terpene alcohol in the leaf extract of mangrove plant Ipomoea tuba. The compounds were identified based on retention times. Table 1 gives the molecular mass and retention times of each compound. Angaye et al. (12) reported various bioactive compounds in the extracts of mangroves Rhizophora mangle, Rhizophora racemosa, Avicennia germinans and Laguncularia racemosa. Phytochemical compounds such as $\beta$-sitosterol, eicosanol and taraxerol are found in Bruguiera cylindrica extract and showed their cytotoxicity against neuro2A cancer cell lines (13).

The bioactive compounds from Avicennia marina, Salvadora persica and Avicennia officinalis contain several types of secondary metabolites like flavonoids, tannins, alkaloids and saponins $(14,15)$. In a previous study, GC-MS analysis of the extracts of Acrostichum aureum confirmed the presence of bioactive compounds such as stigmasterol, $\gamma$-sitosterol, campesterol and 24-methylene cycloartenol with potential activity against adenocarcinoma, carcinoma and other human cancer cell lines (16). Ganesh and Vennila (17) reported the presence of different bioactive compounds, namely terpenoids, steroids, saponins, catechol and phenols in the methanol extracts of Acanthus ilicifolius and Avicennia officinalis. Report from Basyuni et al. (18) showed that the mangrove species Acanthus ilicifolius, Rhizophora apiculata and Sonneratia caseolaris contain a wide range of phytoconstituents like triterpenoids, taraxerol, germanicol and tannins, with anti-inflammatory, anticarcinogenic, antimicrobial and antiprotozoan activities. The mangrove plant Rhizophora mucronata leaf extract contains vindoline, catharanthine and serpentine, the major alkaloids with free radical scavenging and cytotoxic activity (19). The findings of Grozav et al. (20) proved that the derivative of thiazole synthesized from mangrove plant leaves has potential anticancer effect against ovarian cancer cell lines A2780 and HeLa cell lines.

\section{In vitro antiproliferative activity of I. tuba leaf extract on MCF-7 cells}

Extract of $I$. tuba leaves showed significant in vitro antiproliferative effect on MCF-7, and the viability of MCF-7 was reduced with the increase in the concentration of the sample. High reduction of MCF-7 cells was observed at the concentration of $I$. tuba leaf extract of $100 \mu \mathrm{g} / \mathrm{mL}$ (Table 2) and the $I C_{50}$ value against MCF-7 cells was found to be $(40.4 \pm 0.1) \mu \mathrm{g} /$ $\mathrm{mL}$. During experiments, it was observed that the increase in sample concentration altered the morphology of MCF-7 cells, leading to cell death (Fig. 1). Similar findings are reported for in vitro cytotoxicity effect of Avicennia marina extracts on different cancerous cells (21-23). Patra and Thatoi (24) reported the antiproliferative activity of the methanol extract of Heritiera fomes leaves against melanoma cell lines and achieved $40 \%$ inhibition. The methanol extract of Avicennia marina leaf showed anticancer activity against MDA-MB 231 and MCF-7 cell (25).

Table 1. Bioactive compounds identified in the extract of Ipomoea tuba leaf by GC-MS

\begin{tabular}{cccccc} 
Peak no. & $t_{R} /$ min & Compound name & Formula & $M /(g / m o l)$ & CAS number \\
1 & 19.49 & docosanoic acid & $\mathrm{C}_{21} \mathrm{H}_{44} \mathrm{COOH}$ & 340.59 & $112-85-6$ \\
2 & 21.24 & $3,7,11,15$-tetramethyl-2-hexadecene-1-ol & $\mathrm{C}_{20} \mathrm{H}_{40} \mathrm{O}$ & 296.00 & $7541-49-3$ \\
3 & 27.86 & octadecatrienoic acid-ethyl ester & $\mathrm{C}_{19} \mathrm{H}_{32} \mathrm{O}$ & 292.46 & $1191-41-9$ \\
4 & 31.07 & cis-9-octadecanoic acid & $\mathrm{C}_{18} \mathrm{H}_{34} \mathrm{O}_{2}$ & 282.00 & $112-80-1$ \\
5 & 32.80 & $\gamma$-sitosterol & $\mathrm{C}_{29} \mathrm{H}_{50} \mathrm{O}$ & 414.71 & $83-47-6$ \\
\hline
\end{tabular}


Table 2. Inhibition of MCF-7 and HeLa cells using Ipomoea tuba leaf extract

$\begin{array}{ccc}\gamma(\text { extract }) /(\mu \mathrm{g} / \mathrm{mL}) & \begin{array}{c}\text { Viability of } \\ \text { MCF-7 cells/\% }\end{array} & \begin{array}{c}\text { Viability of } \\ \text { HeLa cells/\% }\end{array} \\ 100 & (37.4 \pm 0.1)^{\mathrm{f}} & (41.4 \pm 0.1)^{\mathrm{f}} \\ 75 & (42.0 \pm 0.2)^{\mathrm{e}} & (44.7 \pm 0.2)^{\mathrm{e}} \\ 50 & (45.4 \pm 0.6)^{\mathrm{d}} & (48.3 \pm 1.0)^{\mathrm{d}} \\ 25 & (53.5 \pm 0.8)^{\mathrm{c}} & (51.4 \pm 0.4)^{\mathrm{c}} \\ 10 & (55.8 \pm 0.5)^{\mathrm{b}} & (53.9 \pm 0.3)^{\mathrm{b}} \\ 5 & (60.7 \pm 0.3)^{\mathrm{a}} & (55.6 \pm 0.8)^{\mathrm{a}}\end{array}$

Values are expressed as mean \pm S.D. Values with different letters in superscript in the same column are significantly different $(p<0.05)$ determined by ANOVA
In vitro antiproliferative activity of

I. tuba leaf extracts on HeLa cells

HeLa cell viability was decreased with the increased concentration of leaf extract and the maximum reduction in HeLa cells was observed at $100 \mu \mathrm{g} / \mathrm{mL}$ (Table 2), with the $\mathrm{IC}_{50}$ value of $(37.4 \pm 0.1) \mu \mathrm{g} / \mathrm{mL}$. It was observed that after the treatment with $I$. tuba extract, the HeLa cells slowly detached from one another. Fig. 2 shows the change in morphology of HeLa cells. Khajure and Rathod (26) reported that the extract of A. ilicifolius had cytotoxic activity against HeLa and KB cells. Rajeswari et al. (27) also reported that the flavone molecule from Excoecaria agallocha has the cytotoxic activity against HeLa cells.
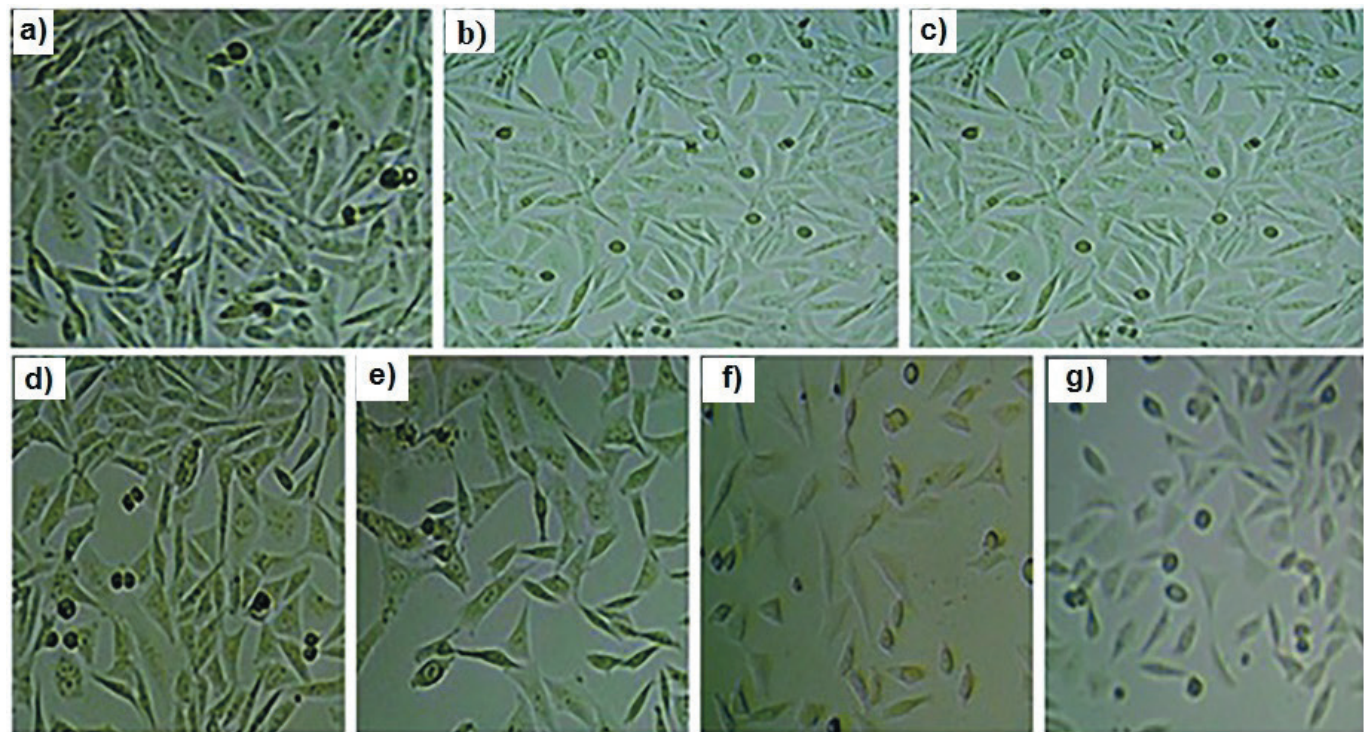

Fig. 1. Morphology of MCF-7 cells after the treatment with the extract of Ipomoea tuba leaf: a) untreated MCF-7 cell lines, and b-g) treated with different concentrations $(5,10,25,50,75$ and $100 \mu \mathrm{g} / \mathrm{mL}$ respectively) of the leaf extract
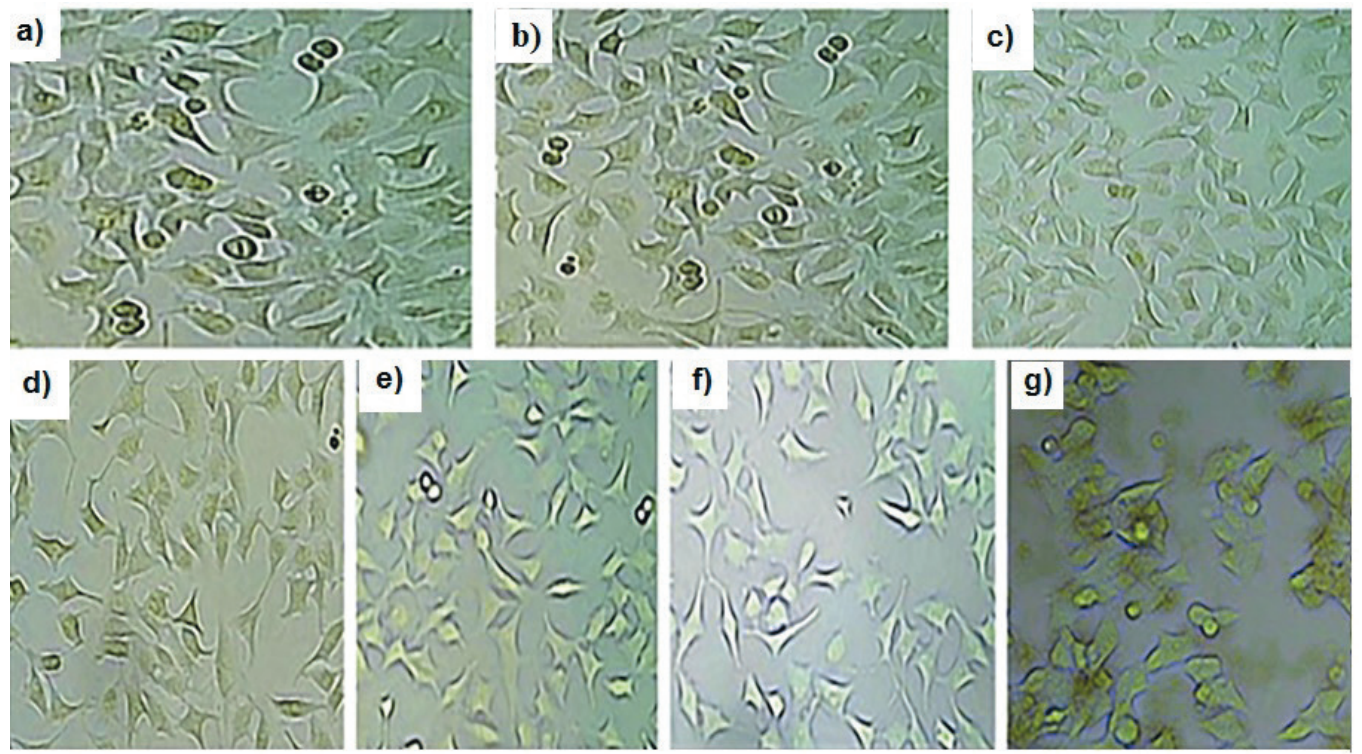

Fig. 2. Morphology of HeLa cells after the treatment with the extract of Ipomoea tuba leaf: a) untreated HeLa cell lines, and b-g) treated with different concentrations $(5,10,25,50,75$, and $100 \mu \mathrm{g} / \mathrm{mL}$ respectively) of the leaf extract 


\section{CONCLUSIONS}

In conclusion, GC-MS analysis confirmed the presence of different phytoconstituents and the Ipomoea tuba extracts were proved to have antiproliferative effect on MCF-7 and HeLa cells. This is the first report of high antiproliferative activity of the extract of I. tuba leaf on MCF-7 and HeLa cells. Furthermore, these bioactive compounds could be used in functional food applications for health benefits.

\section{ACKNOWLEDGEMENTS}

Authors acknowledge the research facilities supported by Fund for Improvement of Science \& Technology Infrastructure in Higher Educational Institutions (FIST Project No: LSI-576/2013), Department of Science and Technology, Government of India and Vignan's Foundation for Science, Technology and Research University.

\section{CONFLICT OF INTEREST}

Authors declare that there is no conflict of interest.

\section{ORCID ID}

T. C. Venkateswarulu (1) https://orcid.org/0000-0002-7822-8860

G. Eswaraiah (1) https://orcid.org/0000-0002-7480-3610

S. Krupanidhi @ https://orcid.org/0000-0001-7702-8974

K. Abraham Peele ㄴ) https://orcid.org/0000-0001-8173-9672

I. Mikkili $\odot$ https://orcid.org/0000-0002-7141-6682

A. Venkata Narayana \ https://orcid.org/0000-0002-5349-0491

B. Kumar Ravuru (1) https://orcid.org/0000-0002-1385-0798

J. Babu Dulla (1) https://orcid.org/0000-0003-4641-915X

A. Ranga Rao (ㄴ https://orcid.org/0000-0002-5735-4489

\section{REFERENCES}

1. Eswaraiah G, Venkateswarulu TC, Krupanidhi S, Abraham Peele K, Indira M, Venkata Narayana A, et al. GC-MS analysis for leaf extract of Suaeda nudiflora and screening of their in vitro anti-proliferative effect against MCF 7 and HeLa cells. Agri Res \& Tech: Open Access J. 2019;22(1):556187.

https://doi.org/10.19080/ARTOAJ.2019.22.556187

2. Eswaraiah G, Abraham Peele K, Krupanidhi S, Kumar RB, Venkateswarulu TC. Identification of bioactive compounds in leaf extract of Avicennia alba by GC-MS analysis and evaluation of its in-vitro anticancer potential against MCF7 and HeLa cell lines. J King Saud Univ Sci. 2020;32(1):740-4.

https://doi.org/10.1016/j.jksus.2018.12.010

3. Record S, Charney ND, Zakaria RM, Ellison AM. Projecting global mangrove species and community distributions under climate change. Ecosphere. 2013;4(3):1-23.

https://doi.org/10.1890/ES12-00296.1

4. Pornpitakdamrong A, Sudjaroen Y. Seablite (Suaeda maritima) product for cooking, Samut Songkram province, Thailand. Food Nutr Sci. 2014;5(9):850-6.

https://doi.org/10.4236/fns.2014.59094
5. Teiten MH, Gaascht F, Dicato M, Diederich M. Anticancer bioactivity of compounds from medicinal plants used in European medieval traditions. Biochem Pharmacol. 2013;86(9):1239-47.

https://doi.org/10.1016/j.bcp.2013.08.007

6. Newman DJ, Cragg GM. Natural products as sources of new drugs over the last 25 years. J Nat Prod. 2007;70(3):461-77. https://doi.org/10.1021/np068054v

7. Akter R, Uddin SJ, Grice ID, Tiralongo E. Cytotoxic activity screening of Bangladeshi medicinal plant extracts. J Nat Med. 2014;68:246-52.

https://doi.org/10.1007/s11418-013-0789-5

8. Eswaraiah G, Abraham Peele K, Krupanidhi S, Indira M, Kumar RB, Venkateswarulu TC. GC-MS analysis for compound identification in leaf extract of Lumnitzera racemosa and evaluation of its in vitro anticancer effect against MCF7 and HeLa cell lines. J King Saud Univ Sci. 2020:32(1):780-3.

https://doi.org/10.1016/j.jksus.2019.01.014

9. Eswaraiah G, Abraham Peele K, Krupanidhi S, Kumar RB, Venkateswarulu TC. Studies on phytochemical, antioxidant, antimicrobial analysis and separation of bioactive leads of leaf extract from the selected mangroves. J King Saud Univ Sci. 2020;32(1):842-7.

https://doi.org/10.1016/j.jksus.2019.03.002

10. Kulkarni A, Govindappa M, Ramachandra YL, Koka P. GC-MS analysis of methanol extract of Cassia fistula and its in vitro anticancer activity on human prostate cancer cell line. Indo Am J Pharm Res. 2015;5(2):937-44.

11. Bhat RP. Anticancer activities of plant extracts of Gymnacranthera farquhariana (Hook. f. \& Thomson) Warb., Myristica fatua Houtt. var. magnifica (Beddome) Sinclair and Samadera indica Gaertner. Adv Obes Weight Manag Control. 2017;6(5):167-71.

https://doi.org/10.15406/aowmc.2017.06.00173

12. Angaye TCN, Ohimain El, Siasia EP, Asaigbe PI, Finomo OA. Larvicidal activities of the leaves of Niger Delta mangrove plants against Anopheles gambiae. Sky J Microbiol Res. 2014;2(7):045-050.

13. Nithyamol Kalappurakkal V, Bhattacharya D, Chakravarty S, Venkata Uppuluri M. Isolation, synthesis and AChE inhibitory potential of some novel cinnamyl esters of taraxerol, the major metabolite of the Mangrove Bruguiera cylindrica. Chem Biodivers. 2018;15(4):e1800008.

https://doi.org/10.1002/cbdv.201800008

14. Bholay AD, Ingale MH, Gaur A. Therapeutic potential of mangrove and its associate plant extracts from thane creek, against human respiratory tract MDR pathogens. J Biol Env Sci. 2015;7(4):118-26.

15. Thatoi H, Samantaray D, Das SK. The genus Avicennia, a pioneer group of dominant mangrove plant species with potential medicinal values: A review. Front Life Sci. 2016;9(4):267-91.

https://doi.org/10.1080/21553769.2016.1235619 
16. Thomas A, Prashob PKJ, Chandramohanakumar N. A profiling of anti-tumour potential of sterols in the mangrove fern Acrostichum aureum. Int J Pharmacogn Phytochem Res. 2016;8(11):1828-32.

17. Ganesh S, Vennila J. Phytochemical analysis of Acanthus ilicifolius and Avicennia officinalis by GC-MS. Res J Phytochem. 2011;5(1):60-5. https://doi.org/10.3923/rjphyto.2011.60.65

18. Basyuni M, Putri LAP, Oku H. Phytomedicinal investigation from six mangrove tree species, North Sumatra, Indonesia (Invetigasi Fitomedisinal Enam Spesies Mangrove, Sumatera Utara, Indonesia). Ilmu Kelautan. 2013;18(3):157-64. https://doi.org/10.14710/ik.ijms.18.3.157-164

19. Gurudeeban S, Ramanathan T, Satyavani K. Antimicrobial and radical scavenging effects of alkaloid extracts from Rhizophora mucronata. Pharm Chem J. 2013;47:50-3. https://doi.org/10.1007/s11094-013-0895-4

20. Grozav A, Porumb ID, Găină LI, Filip L, Hanganu D. Cytotoxicity and antioxidant potential of novel 2-(2-( $1 \mathrm{H}$-indol-5yl) methylene)-hydrazinyl)-thiazole derivatives. Molecules. 2017;22(2):260. https://doi.org/10.3390/molecules22020260

21. Karami L, Majd A, Mehrabian S, Nabiuni M, Salehi M, Irian S. Antimutagenic and anticancer effects of Avicennia marina leaf extract on Salmonella typhimurium TA100 bacterium and human promyelocytic leukaemia HL-60 cells. Sci Asia.
2012;38(3):349-55

https://doi.org/10.2306/scienceasia1513-1874.2012.38.349

22. Sukhramani PS, Patel PM. Biological screening of Avicennia marina for anticancer activity. Pelagia Res Lib. 2013;4(2):125-30.

23. Shanthi N, Murugesan S, Janetta Nithia SM, Kotteswari M. In vitro anticancer activity of methanol extracts of $A v$ icennia marina (Forssk) Vireh against HepG2 liver hepatocellular carcinoma cancer cell line. Int J Recent Sci Res. 2018;9(10):29122-6.

https://doi.org/10.24327/ijrsr.2018.0910.2796

24. Patra JK, Thatoi H. Anticancer activity and chromatography characterization of methanol extract of Heritiera fomes Buch. Ham., a mangrove plant from Bhitarkanika, India. Orient Pharm Exp Med. 2013;13:133-42.

https://doi.org/10.1007/s13596-013-0113-7

25. Momtazi-borojeni AA, Behbahani M, Sadeghi-aliabadi $H$. Antiproliferative activity and apoptosis induction of crude extract and fractions of Avicennia marina. Iran J Basic Med Sci. 2013;16(11):1203-8.

26. Khajure PV, Rathod JL. Potential anticancer activity of Acanthus ilicifolius extracted from the mangroves forest of Karwar, West coast of India. World J Sci Technol. 2011;1:1-6.

27. Rajeswari K, Rao TB, Sharma GVR, Muralikrishna R. Anticancer activity of flavone of Excoecaria agallocha in cytotoxicity studies using Hela Cells. Asian J Chem. 2017;29(11): 2406-08. https://doi.org/10.14233/ajchem.2017.20724 